\title{
VÁROSI TEREK KORMÁNYZÁSA ÉS A VÁROSI REZSIMEK. EGY INDULÓ KUTATÁS MARGÓJÁRA ${ }^{1}$
}

\author{
(Governance of Urban Spaces and the Urban Regimes. \\ On the Margine of a Starting Research Project) \\ PÁLNÉ KOVÁCS ILONA
}

\begin{abstract}
Kulcsszavak:
városi terek agglomerációk városi rezsim hálózatok

A tanulmány egy 2010-ben indult OTKA kutatás egyik metszetének elméleti megalapozását szolgálja. Abból indul ki a szerző, hogy a városok térszervezö, agglomeratív funkcióinak intézményesitése során számolni kell azzal, hogy a városi gazdaság szereplöi jelentös hatást gyakorolnak a városok fejlödésére, müködésére, s ezt a szerepet célszerü optimálisan intézményesiteni, elhelyezni a döntéshozási rendszerben. A tanulmány arra törekszik, hogy számba vegye a kutatáshoz kapcsolható elméleti elözményeket, s kiinduló pontot adjon a kutatási módszertan kidolgozásához.
\end{abstract}

\section{A városi kormányzás változó szerepe és szereplői}

A kormányzati rendszerek térbeli modelljeinek kialakítása, kutatása, értékelése mindig kiemelten kezeli a városok szerepét. Azt is mondhatjuk, hogy a városok az igazgatási tér strukturáló elemei éppen azért, mert a város a kerete a különböző közösségi funkcióknak nem csupán az ott élők, hanem a szükebb-tágabb környék számára is. A városok térbeli szerepét illetően mindig is megkülönböztető vonás volt a kifelé sugárzás, a környék vonzása és ellátása, a térbeli kapcsolatok generálása, mégis adós az igazgatástudomány a városi hálózatok markáns térstrukturáló funkciójának intézményesítésével.

A térbeli közigazgatási reformtörekvések még a legutóbbi évtizedben is elsősorban a régiók, az erős kormányzati középszintek kialakítására irányultak, annak ellenére, hogy mind a gazdaság, mind a szolgáltatás-fejlesztési szakpolitikák szakirodalma és hivatalos kormányzati dokumentumai rendre másra kiemelik a városok, városi hálózatok, agglomerációk kitüntetett szerepét. A legutóbbi időszakban a versenyképesség, a globális kihívások tükrében fogalmazódik meg a városok dimenziója, és mint Szirmai kifejti, a nagyvárosok megoldást jelenthetnek a politikai rendszerváltások sokkján áteső posztszocialista országok világgazdasági csatlakozása számára is (Szirmai 2004).

A ,városi reneszánsz” a tradicionális területi közigazgatás-szervezést több szempontból új kihívások elé állította. A városok gazdaságát, infrastruktúráját és társadalmát érő változások felgyorsultak, e változások kezelésében alapvetővé vált a helyi kormány- 
zatok szerepvállalása, felismerve, hogy helyi/területi szinten lehet igazán elérni a hatékonysági és demokratikus követelmények szinergiáját (Hambleton et al. 2003, 149).

A városokra épülő gazdaságfejlesztési és szolgáltatási politika nemcsak értékrendbeli, illetve szemléleti változást tesz szükségessé, hanem az önkormányzati, igazgatási intézményrendszer strukturális és müködési reformját is. A hagyományos közpolitikai és szükebb közigazgatási intézményrendszer elsősorban területi egységekben, irányítási szintekben, illetve ágazati szemléletü, egyközpontú, hierarchikus irányítási mechanizmusban gondolkodik, miközben a városok aktívabb szerepvállalása, térbeli integráló erejének növelése hálózatos, horizontális irányítási elemeket, eszközöket tenne szükségessé. Sajátos módon, miközben a városok funkcionálisan „uralják” a teret, addig érdekeik formálisan alulképviseltek, illetve informálisak, a jelenlegi irányítási rendszerekben. Kérdés, hogyan vezethető át a városi dimenzió a hagyományos struktúrákba? A feladat egyáltalán nem egyszerü, hiszen a területi közigazgatás-szervezés mindenütt a világon küzd ezzel a problémával, speciális intézményekkel kísérletezik, tehát aligha vehetők át bevált modellek.

Lényegében két fö áramlat létezik, az egyik a várost és környékét szoros intézményesített kapcsolatba, ha úgy tetszik ,szintbe” füzné, míg a másik a lazább, hálózatos együttmüködési formákat tartja hatékonyabbnak. A törésvonalak végül is a szabályozásba, intézményekbe vetett hit erőssége mentén húzódnak, s attól is függnek, hogy az adott közigazgatási intézményrendszer milyen politikai, kulturális környezetben müködik. A konkrét megoldások hatékonysága sokszor nem is a modellválasztástól, hanem a szereplők alkalmasságától, a konkrét földrajzi, társadalmi, gazdasági környezettől függ.

A szakirodalom az utóbbi évtizedekben rámutatott arra, hogy a városi kormányzás kinövi a klasszikus önkormányzati, képviseleti modellt, ami szükségessé teszi a hagyományos közjogi döntési mechanizmusok újraszabályozását. A képviseleti demokrácia hagyományos értékei, intézményei általában is átalakulnak, a deliberatív elemek felértékelődése nyilvánvalóan az önkormányzati rendszert is érinti. Lokális dimenzióban is jelentkezik a demokratikus deficit problémája, a közvetlen állampolgári részvétel, a nyilvánosság korlátozottsága, az informalitás növekedése, ezekre igyekeznek sajátos válaszokat adni hol felülről, szervezetten, hol alulról induló kezdeményezések, mozgalmak formájában. A lokális politika demokratikus deficitje különösen jellemző az urbanizált terekben. A városi kormányzatok méretének növekedése, összetetté válása miatt vált szükségessé a városon belüli decentralizáció, a demokratikus részvétel különböző formáinak a kialakítása (kerületek, részönkormányzatok, bázisközösségek, szomszédságok stb.). További sajátosság, hogy a városok kormányzásában egyszerre kell belső és külső, a városfalakon kívüli szereplők együttmüködését megszervezni, a közgazdasági értelemben leírt spillover hatásokat politikai, közigazgatási mechanizmusokkal kezelni. Ilyen értelemben a városi kormányzás és annak térbeli dimenziói szoros kapcsolatban vannak a többszintü kormányzás jelenségével (Sagan 2009), túlterjedve a nemzeti jelentőségen.

A városokban felszaporodó szolgáltatási, adminisztratív, hálózati funkciók ellenére a nagyvárosi kormányzatok többsége még nem formalizálta integrációs szerepét, ha 
úgy tetszik, intézményi szempontból felkészületlen mind a gazdaságfejlesztésben, mind a térszervezésben rá váró feladatokra. Kétségtelen, hogy a középszintü önkormányzatok és a metropoliszok összekapcsolásának problémájára nehéz általános modellekkel szolgálni (Berg et al. 1997; Somlyódyné Pfeil 2008b; Tosics 2008). A különböző országok, városok próbálkozásai sok tanulsággal jártak, de nem vezettek a területi kormányzás alapvetően szintekbe szerveződő modelljének gyökeres átalakulásához. A városok kormányzása lényegében a szintekbe, hierarchiába szerveződő közigazgatással szembeni „horizontális, hálózati” kihívás a városok és környékük kormányzatai között, kiegészülve a közszektor mellé felzárkózó nem közhatalmi ,horizontális partnerekkel”.

A horizontalitás egyik nagyon fontos, s talán legkevésbé megoldott eleme a közhatalmi és üzleti szféra közötti viszony. A gazdasági folyamatok globalizálódása, a városok közötti verseny megjelenése a gazdasági szereplőkkel való viszonyrendszert új dimenzióba helyezte, gyakran problémákat, konfliktusokat idéznek elő a hagyományos kormányzati szerkezetben. Az általános, egyenlő választójogra épülő modern demokráciákban teljesen idegen a középkorban érvényesülő „,virilizmus” elve, amelynek logikája arra épült, hogy a legtöbb adót fizetők, a legnagyobb vagyonnal rendelkezők viszonya, érdekeltsége a helyi közösségi döntésekhez más a vagyontalanokhoz képest. A virilizmust valamelyest továbbéltető korporatív formák beépülése a plurális demokratikus rendszerekben gyakran instabil, ,kivételes”. A magán, illetve a gazdasági érdek követése és a közfunkciókkal való összeegyeztetése szinte mindig problematikus a politikai és különösen a morális értékrendben (Schneider 2002). A gazdaság és politika kapcsolatát emiatt alapvetően az informalitás jellemzi, aminek hátránya nemcsak a nyilvánossághoz, átláthatósághoz kötődő demokratikus érték csorbulásában jelölhető meg, hanem a kiszámíthatatlanságban is.

A helyi kormányzatokat elemző kutatások már a hetvenes években rámutattak arra, hogy a helyi igazgatás bürokratikus kötöttségei egyre kevésbé alkalmasak a gazdasági környezettel való kapcsolattartásra, az új kihívásokhoz való alkalmazkodásra. A helyi gazdasági koordinációnak két fajtája a centrális, amikor az önkormányzat egyedüli generálója a folyamatoknak, illetve a résztvevők kölcsönös alkalmazkodására épülö horizontális koordináció (Rückwardt 1978). E két típus közül az utóbbi bizonyult életképesebbnek, ami viszont a helyi kormányzatok müködési mechanizmusainak, eszközeinek jelentős átalakítását igényelné. Ezért hívják fel a figyelmet arra, hogy a müködési módszereket és formákat, intézményeket a megváltozott körülményekhez kell igazítani, a helyi politika egyes szektoraiban sokszínű kapcsolattartási formáknak kell kialakulnia (Stoker 2000). A formálódó válaszokkal kapcsolatban azonban kezdetektől megfogalmazódtak aggályok is. A gazdasági és önkormányzati szereplők közvetlen konzultációja gyakran kizárja a nyilvánosságot, a közvetlenül választott demokratikus fórumok szerepét az elődöntések szentesítésére korlátozza. Németországban már évtizedekkel ezelött is vita folyt arról, hogy az ún. inszcenált korporatizmus veszélyt jelenthet a helyi demokrácia klasszikus képviseleti intézményrendszerére (Heinze-Volezkow 1991). Az Egyesült Királyságban a public-private szerveződések, a városfejlesztéssel, továbbképzéssel foglalkozó 
korporációk gyakran központi kormányzati ellenőrzés mellett működtek, ezért a helyi önkormányzatok kiszorításának, tehát a centralizáció eszközeként értékelik (Duncan-Goodwin 1988; Lewis 1992; Martin 2010). Az utóbbi évtizedek kormányzási rendszereit jellemző ún. horizontális hálózatosodásról is az a vélemény alakult ki, hogy kétségtelenül csökkenti a helyi és regionális kapcsolatrendszerek megosztottságát, javítja a fejlesztési politikák hatékonyságát (Amin-Thrift 1995), ugyanakkor kikezdi a demokrácia bizonyos értékeit (részvétel, nyilvánosság, átláthatóság).

A városi kormányzás előtti kihívások tehát meglehetősen komplexek. A funkciók kiterjedése, a városi vonzáskörzetek összetettebbé válása, a városi hálózatok erős összekapcsolódása, térformáló szerepe új helyet és intézményesítést követel a térbeli kormányzás rendszerében. Ugyanakkor a városok kormányzása belülről is átalakul, új szereplők, viszonyrendszerek jelennek meg, amelyek átalakítják, relativizálják a klasszikus városi önkormányzás modelljét. A modern társadalom és gazdaság problémái a városi térben koncentráltan jelennek meg, amelyekre a központi szint már nem, a város viszont még nem alkalmas hatékonyan reagálni: „A város már nem az a tér, amelyik a megoldásokat kínálja, sokkal inkább olyan aréna, ahol a megoldásokra szükség van.” (Kearns-Paddison 2000, 849)

Tanulmányunkban egy OTKA kutatás részeként induló vizsgálat (OTKA 81789) elméleti, módszertani összefüggéseit járjuk körbe. A kutatás a fenti kettős kihívás egymásra való hatását kívánja elemezni, tehát azt, vajon a városi kormányzás szereplői és azok viszonyrendszere vonatkozásában bekövetkezett változások befolyásolják-e a városok térbeli kormányzási szerepét, a városon belüli hálózatok kilépnek-e a városi vonzástérbe, vajon a támogató szövetségben kormányzó városok sikeresebbek lesznek-e térbeli kapcsolataik kiépítésében, vajon a fejlesztési szövetségek térben versenyt vagy kooperációt generálnak?

\section{A városi rezsim és néhány rokon elmélet alkalmazhatóságáról}

\section{Helyi közösség kutatások (local community studies)}

Mielőtt a városi rezsim elmélet ismertetésébe kezdenénk, fontos az előzmények között megjegyezni, hogy a gazdaság és helyi társadalom, politika viszonyrendszere korábbi helyi politikakutatásoknak is tárgya volt. A mintaértékünek tekintett Lynd-ék vezette Middletown-vizsgálatban, illetve a tübingeni egyetem kutatócsoportja által Wolfsburgban, a Volkswagen Müvek székhelyén folytatott elemzések e problémakör dinamikáját is elemezték. A wolfsburgi 1960-ban végzett, majd 1980-ban megismételt vizsgálat egyértelmüen kimutatta, hogy a „Müvek” befolyása megmaradt, változott azonban a befolyásolás módja, újabban kevésbé direkt, illetve egyoldalú, illetve autokratikus. A Müvek vezetői, alkalmazottai kivonultak a helyi testületi képviseletből, a kapcsolatokat a menedzsment és a tisztségviselők közvetlenül ápolják (Herlyn-Schweitzer-Tessin-Lettko 1982). Paradox módon a befolyás fogalmi körébe tartozik az a jelenség is (amely a globalizálódással gyakorivá válik), amikor 
a gazdálkodó szervezet tudatosan távol tartja magát a helyi politika intézményeitől és müködésétöl, s ezzel olyan hatalmi vákuumot teremt, amelyben az információk és a támogatás hiánya miatt döntésképtelenség állhat elő. Az esetleg sorozatosan jelentkező konfliktusokban a helyi vezetés felörlődik, képtelenné válik integratív funkciójának betöltésére. A település hatalmi szférákra szakad, önállóságának maradékát felszippantja a vertikális szervezetek atyáskodó beavatkozása (Dahl 1961; Aiken-Mott 1970; Kriesi 1983).

\section{A városi rezsim}

A városi rezsimek (urban regime) elmélete a városok fejlesztési forrásokért, befektetőkért folytatott versenyének jelenségére épül, ezért helyezi érdeklődésének fókuszába a helyi gazdaságfejlesztés és a helyi politikai viszonyok új összefüggésrendszerét. Sokan vitatják e megközelítés újdonságát (hiszen az eredmények nem térnek el jelentősen a korábbiaktól), a gazdasági szektor privilegizált helyzete a helyi hálózatokban továbbra is jellemző, legfeljebb a technikák, intézmények változnak (Judge et al. 1995). De nem is ebben áll az urban regime iskola újszerüsége, hanem az érdeklődés fókuszában, nevezetesen, hogy milyen módon járulnak hozzá ezek a fejlesztési, növekedési koalíciók a helyi gazdaság és a város fejlödéséhez. A városi rezsim iskola nagyon közel áll a gazdaságfejlesztéssel foglalkozó közgazdasági megközelítések közül az ún. közösségi alapú fejlesztési iskolához, amelyik azt vallja, hogy a gazdaságfejlesztés aktuális föirányával szemben a különbözö helyi-regionális fejlesztési gyakorlatok alternatívákat jelenthetnek (Pike et al. 2006), s a helyi fejlesztési rezsimek az általános gazdaságpolitikai környezettel szemben megalapozhatnak helyi ideákra épülő alternatív stratégiákat (Rast 2005). Ennek azonban természetesen megvannak a kormányzási, intézményi feltételei.

A városi rezsim elmélet az 1980-as években jelent meg az USA-ban, melynek elméleti és módszertani stabilitása, önállósága lényegesen gyengébb a hatvanas, hetvenes években virágzó local community studies elitista és pluralista iskoláihoz képest (Stoker 1995), sokan azt is vitatják, hogy alkalmazható-e az USA-n kívül, tekintettel a nagyon sajátos közpolitikai modellre (Harding 1999). Noha jelentős mértékben támaszkodik a korábbi kutatási előzményekre, ennek az elméletnek egyik megkülönböztető vonása, hogy szükebb spektrumra fókuszál, mégpedig a helyi kormányzati és nem kormányzati szektor kölcsönös függőségére. A szükebb vizsgálódási kör ellenére az urban regime iskola a városi kihívásokra adható válaszok széles skáláját dolgozta ki. Már csak azért is képes volt erre, mert éppen legfontosabb erényének azt tartják, hogy képes volt integrálni a mikro és makro összefüggések kölcsönös hatását, $\mathrm{s}$ a formális és informális hatalmi folyamatok mélyebb szintü megismerését (Sagan 2009).

A korábbi marxista, neomarxista felfogásokkal ellentétben, amelyek a gazdaság determinista felfogását képviselték, az urban regime iskola már évtizedekkel ezelőtt azt ismerte fel, hogy a helyi kormányzás rendelkezik bizonyos mozgástérrel. 
A hagyományos politikai/önkormányzati intézmények, szereplők önmagukban azonban már nem képesek adekvát válaszokra, ráadásul vagy éppen ezért a várospolitika fontos csoportjainak érdekeit figyelmen kívül hagyják.

Az urban regime képviselöinek elemzései különösen a gazdasági szektor szerepét emelik ki, amelyet nélkülözhetetlennek tartanak a helyi kormányzásban, de elfogadva ugyanakkor, hogy e szektor lényegében korlátozza a demokratikus intézmények müködését. Nagyon fontos, hogy az elmélet közvetlen elözményeként értékelhető növekedési gépezet (growth machine) elmélettől eltérően az üzleti kör szerepét nem értékeli túl, miután a gazdasági szereplők befolyása inkább a sikeres, növekedő városokban és ciklusokban mutatható ki markánsan. Az elmélet elutasítja az ún. hiperpluralisták pesszimista véleményét, miszerint a városok kormányzása olyan mértékben összetetté vált, hogy a helyi kormányzatok már nem is képesek uralni ezt a bonyolult hálózatot (Clark 2003), azt vallva, hogy a városi rezsimek új fejlődési pályát jelentenek a helyi kormányzás számára.

Az urban regime elmélet egyik legismertebb képviselöje, Stone szerint, a városi kormányzás intézmények és szereplők rendkívül komplex, megosztott hálózata, amelyből eredendően hiányzik a konszenzus (Stone 1989). A hatékony kormányzás feltétele, hogy az önmagában korlátozott kapacitású helyi önkormányzat segítségével a nem kormányzati szereplők viszonylag stabil informális csoportja hozzáfér az intézményi forrásokhoz, amelyek alapján befolyása fenntartható a helyi döntéshozásban (Stone 1991). A korábbi helyi közösség kutatásokhoz (local community studies) iskolához képest az új kérdésfeltevés nem az, kié a hatalom (ahogy Dahl fogalmazott: Who governs?), hanem, hogy hogyan lehet a kapacitásokat egyesíteni a közös érdekek megvalósításáért (Stoker 1995). Ahogy Stone szellemesen megkülönböztette a hagyományos kormányzattól a konkrét célok megvalósítására irányuló rezsimet, az elöbbi a valami fölött, az utóbbi viszont a valamiért gyakorolt hatalom (power „over”, power „to”) (Stone 1989, 229). A rezsim teória ezzel, ahogy a névválasztás is szimbolizálja, elszakítja magát a hagyományos demokrácia felfogásoktól, amelyik a hatalmi pozícióra s nem a hatalom funkciójára koncentrál. Stone saját elméletét évtizedek távolságából sem tartja ugyan középszintü elméletnek, abban megjelölve nézete lényegét, hogy az intézményi, strukturális összetevők jelentősége mellett a személyi/emberi kombinációkra, a magatartást befolyásoló mikro körülményekre koncentrál. Ez a megközelítés ennyiben távolságot tart a racionális döntési (public choice) elmélettöl is (Stone 2005).

Eltérően a helyi közösségkutatások pluralista és az elit elméletétől egyaránt, a rezsim iskola, mint említettük, a választott képviseletnek nem tulajdonít elsődleges jelentőséget, és azt sem állítja, hogy mindenki egyenlő hatalommal, partnerként vesz részt a döntéshozásban, a hatalmi szerkezet tehát aszimmetrikus. A hálózaton belüli pozíció különösen a társadalmi tranzakciók stratégiai ismerete és az ennek megfelelö cselekvéshez szükséges kapacitás, továbbá a források feletti kontroll lehetőségén múlik. A figyelem elsősorban nem a szereplőkre, hanem a koalícióképződés mechanizmusára irányul, illetve az eredményességre, s nem arra, hogy azzal a nyilvánosság mennyire ért egyet. A célok kitüzése, a koalíció létrehozása arra irányul, 
hogy mi az, ami végrehajtható, és kik azok, akik a leginkább képesek elösegíteni az eredményt. Minél nagyobb településről van szó, annál inkább van esélye azonban egyéb szereplőknek is a hálózatba kapcsolódásra. Stone szerint a városi politika minőségét a kormányzó koalíciók összetétele, a koalíción belüli kapcsolatok és a tagok által kontrollált források mennyisége, minősége szabja meg (Stone 1993). A rezsim többnyire nem egyéni érdekeket érvényesítö, alkalmi szövetkezést jelent, hanem a városi környezettel szembeni tudatos, hosszú távú stratégia követését (amibe beleértendő a kirekesztés és a bevonás is), tudatos kislépések megtervezését, a végrehajthatóság képviseletét az értékpreferenciák helyett, a sikerességet az absztrakt nyilvánosság, közösségi támogatottság helyett (Stone 1993). E modellnek nem az a lényege, hogy valamifajta elit kiválasztódik és kormányoz, hanem az, hogy kialakulnak és fenntarthatóak a tartós és szabályozott partnerség feltételei. Keating mutatott rá a francia példán keresztül arra, hogy a felsőbb irányítási szintekkel való kapcsolatnak, forrásbevonó képességnek is nagy jelentősége van (Keating 1991; 1993). Nem szabad megfeledkezni azonban arról, hogy a rezsimek egyaránt lehetnek exkluzív és befogadó jellegúek, tehát a partnerség lehet zárt és nyitott is, ami gyökeresen mást jelent a plurális képviseleti kormányzás filozófiájához képest. Az elméletre támaszkodva például, vannak törekvések arra, hogy a korábbi modellt összekapcsolják a kormányzás új, regulatív megközelítésével, amely nagyobb szerepet tulajdonít a közszektor szabályozó szerepének (Lauria 1997).

A rezsim elmélet általában négyfajta hatalmi formációt különböztet meg. Az ún. rendszer-hatalom, lényegében a hagyományos, közjogi legitimációval rendelkező intézmények összessége, az utasító-társadalmi ellenőrző hatalom ágazati, technokrata karakterü, a koalíciós hatalom különbözö befolyási forrásokra épülő, de egységes szövetség. A negyedik, ún. társadalmi termék hatalom a legnehezebben elérhetö, de a legsikeresebb formáció, amely közösségi támogatásra épül, s hosszabb távon biztosít stabilitást a rendszerhatalomhoz képest (Sagan 2009, 96). A hatalom stabilitása azon múlik, hogy sikerül-e elkerülni valamelyik partikuláris szereplő tartós dominanciáját. Stoker és Mossberger a céljuk alapján a rezsimek három kategóriáját azonosította annak érdekében, hogy koncepcionális keretet nyújtsanak a nemzetközi összehasonlításhoz. Az instrumentalista rezsimet rövidtávú, konkrét célok formálják, s erősen szelektív, az organikus rezsim az adott lokalitás közös tradícióira épül, gyakran ellenáll a változásoknak, a szimbolikus rezsim éppen ellenkezőleg, a manipulált szimbólumok segítségével a változást forszírozza (Stoker-Mossberger 1994), különösen akkor alkalmazva ezt a módszert, ha nincs más alapozó tényező a koalícióképződésre.

Maga Stone pedig négy fajta rezsimet azonosított az USA-ban aszerint, hogy milyen célokat szolgálnak, s milyen csoportok alkotják (Stoker 1995, 61):

- Az ún. fenntartó rezsim nem a változásra, hanem az állapot megtartására törekszik, összetételét a helyi hatalom hagyományos szereplöi uralják.

- A fejlesztó rezsimeknek több forrásra és komplexebb koalícióra van szükségük a növekedés vagy a kríziskezelés érdekében, tagjaik jórészt a dinamikus gazdasági szereplők közül kerülnek ki. 
- A középosztálybeli ún. progresszív rezsim a különleges értékeket, például a környezetet védi a gazdasági növekedéssel szemben.

- Az alsóosztálybeli, a lehetőségeit kereső rezsim az, amelyik, többnyire jóléti, foglalkoztatási céljait nagyobb csoportok mozgósításával igyekszik elérni.

\section{A governance-paradigma}

A rezsim iskola szemlélete természetesen nem szigetszerü, szorosan összefügg más, tágabb perspektívájú társadalomtudományi irányzatokkal, amelyek a legtágabb értelemben kapcsolódnak a governance meglehetősen komplex, esetenként zavaros, éppen ezért néha nem segítő, inkább kirekesztő fogalmához (Rhodes 1997). A governance megközelítések egyrészt tágabb, politikatudományi értelemben az állam és társadalom viszonyrendszer változásait keresik, beleértve a reflexivitás formáit, új együttmüködési mintáit. A governance szükebb, inkább policy megközelítésben a közösségi és magánszektor intézményei közötti határvonalak felbomlása, önszabályozó, szervezetközi hálózatokká formálódása (Peters-Pierre 2006).

Rhodes végül is az új típusú kormányzást (governance) egy önszabályozó, szervezetek közötti hálózatként írta le, amelyben

- $\quad$ az érintett szervezetek között kölcsönös függőség van;

- a hálózatok között folyamatos interakciók tapasztalhatóak;

- ezek az interakciók ,játékszerüek”, meghatározott szabályokkal, bizalomra épülve;

- $\quad$ s mint hálózat viszonylag független az államtól, noha indirekt módon a hálózatot kormányzó befolyása van (Rhodes 1997, 52).

A governance típusú kormányzás kutatói nem tekintik ma már a modellt panaceának, felismerve, hogy a szereplök közötti formalizált és informális viszonyrendszer pluralizálódása miközben adott helyzetekben jól müködik, a demokratikus képviseleti rendszer és a piac „hibáinak” hatékonyabb helyi megoldásához vezet, ugyanakkor egyben új problémák forrása. „Partnerség vagy párhuzamos struktúrák”, teszi fel a kérdést tanulmányában Giguére (2002; 223), arra utalva, hogy a szerte Európában különösen a fejlesztéspolitikában elterjedt partnerségi hálózatok nyomán esetenként túlságosan fragmentált döntési és végrehajtási intézményrendszer alakul ki, rontva a hatékonyságot. Még nagyobb probléma származik az elszámoltathatóság hiányából, illetve a partnerségi struktúrákkal együttmüködő közhatalmi intézményrendszer rugalmatlanságából.

Egyre gyakrabban vetődik fel a kérdés, vajon a sokdimenzióssá, intézményi szempontból átláthatatlanná kuszálódó mechanizmusok jobban megbirkóznak-e az innováció kényszerével, mint az egyközpontú, erős kormányok? A választ keresve az a vélemény alakult ki, hogy a kooperatív struktúrák, amelyek növekvő számban vonnak be szereplőket a helyi hatalmi arénába, nem helyettesíthetik, csupán kiegészítik a képviseleti és közvetlen demokrácia intézményeit (Bovaird et al. 2002). 
A civil szektor és a közhatalmi rendszer összefüggésrendszerében a civil vagy magán szektornak különböző modellek szerint van lehetősége közvetett vagy közvetlen kapcsolatba kerülni közösségi döntéshozókkal, betölteni az érdekközvetítés szerepét. Ott képes a leginkább érvényesíteni az ,áthidaló ügynökség” szerepet, ahol a köz- és a civil szektor között folyamatos diskurzus zajlik. E diskurzus és kapcsolatrendszer ugyan alapvetően a politikai rendszer sajátosságaitól függ, mégis mutat közpolitikai, ágazati és helyi sajátosságokat is (Heinelt 2002). Különösen kiterjedt irodalma van az ún. közpolitikai hálózatoknak, amelyek az adott közpolitika (fejlesztéspolitika, környezetvédelem, közoktatás stb.) értékrendje, forrásszerkezete mentén formálja a szereplők körét és a cselekvési arénát.

A helyi kormányzás fő szereplői egy tanulmánykötet szerzői szerint az egyének, az önkéntes civil szektor (beleértve a pártokat, szakszervezeteket is), az üzleti szféra, a média, a felsőbb irányítási szintek résztvevői és a helyi hatóságok (Bovaird et al. 2002, 13). Az egyes szereplők tényleges befolyása, az együttmüködés mechanizmusai tekintetében rendkívül tarka a kép, amelynek az empirikus feldolgozása is kezdetleges. Az említett kutatás eredményei szerint az üzleti szektorral és a médiával való kapcsolat minősül legtöbbször és legtöbb országban valóban partnerinek, kölcsönösnek, míg a helyi társadalom egyéb csoportjai, mint „célcsoportok” irányában továbbra is egyenlőtlen, hierarchikus a viszony, s alakulásában inkább a bizalom mértéke játszik szerepet (De Vries 2002).

\section{A közpolitikai hálózat (policy network)}

A városi rezsim iskola különböző elemeit megtaláljuk a közpolitikai hálózatok (policy network) elméletében is. A hálózati megközelítés segítségével remélhetően kitapinthatóak lesznek a szereplők, a köztük lévő viszonyrendszerek, segítve a városi kormányzás intézményi, normatív és eljárási kereteinek megújulására vonatozó javaslataink kidolgozását. A hálózat fogalma nem új, nem is egyértelmü, vannak, akik babiloni hangzavart érzékelnek körülötte (Börzel 1998), de a kormányzás (governance) szempontjából kétségtelenül reneszánszát éli, már elsősorban nem is elméletként, hanem elemzési eszközként. Heclo szerint nem az egyéni döntések közösségivé formálása felől, hanem a szereplők interakcióiból formálódó hálózatok felől lehet a politikákat és a hatalom természetét megérteni (Heclo 1972). A hagyományos amerikai tripartit megközelítést meghaladva, amely az érdekcsoportok, bizottságok és a végrehajtó igazgatás vasháromszögében jelölte meg a hálózatok lényegét (Jung 2010). Heclo megkülönböztetett policy közösségeket és ún. ad hoc issue (konkrét ügyekre irányuló) hálózatokat. A későbbi szakirodalomban megjelent a pártfogó koalíciók (advocacy coalition) fogalma, amely a korábbi leegyszerüsített modellek helyére egy összetettebb, több alcsoportból álló hálózatot ír le, amelyek különböző technikákat, szereplőket (például policy brókereket) alkalmazva törekszenek közös céljaik elérésére, a közösséget a közös értékrend „ragasztja” össze (Sabatier-Jenkins-Smith 1993). 
A hálózatelemzések hatalmas irodalma, mintái tekintetében hajlunk arra, hogy az egyre elterjedtebb ún. új pragmatikus megközelítést válasszuk, amely elfogadja a módszerek és megközelítések, fogalmak folytonosan változó természetét, nyitott a kemény statisztikai információk mellett egyéb információs csatornákat is elfogadni (Peters-Pierre 2006). Számunkra nem igazán az a fontos, hogy a konkrét terepen azonosítsuk a rezsim tagjait, sokkal inkább az, hogy megtudjuk, a városok térbeli szervező funkciói számára a leggyakoribb tagok milyen hozzájárulást nyújtanak, vagy éppen milyen módon segítik vagy akadályozzák az optimális együttmüködések megvalósulását.

A policy network jellemzőit Rhodes az alábbiak szerint foglalta össze (Rhodes 2000):

- limitált részvételt biztosít,

- kijelöli a szereplőket,

- a hálózat dönt a napirendre kerülő kérdésekről,

- a kialakított játékszabályok formálják a szereplők viselkedését,

- a hozzáférés esélye és a közpolitikai értékrend alakítja a privilegizált érdekek körét,

- a magán elszámoltathatóság helyettesíti a közösségit.

A közpolitikai hálózat elmélet segítségével kiválaszthatjuk a városi kormányzás néhány fontos területét és szereplőjét, amelyek alapvetően meghatározzák a városok, illetve a város és környéke együttmüködését. Tekintettel arra, hogy a rezsim elméletet sok szempontból kiindulópontnak tekintjük, ezért nyilvánvalóan olyan közpolitikai területek elemzése indokolt, ahol a fejlesztésben érdekelt szereplők a leginkább részt vesznek, érintettek.

Különösen ígéretesnek tünik az uniós és nemzeti regionális fejlesztéspolitikákban, az utóbbi évtizedekben kialakult partnerségi együttmüködések tapasztalatainak adaptálása, azzal a nem jelentéktelen eltéréssel, hogy ezek a fejlesztési partnerségek lényegében uniós vagy állami közpénzek, támogatások felhasználásához kötődnek, sok esetben közjogilag formalizáltak, intézményesítettek. Az uniós strukturális alapokhoz kötődő ,ffejlesztési rezsimek” müködési tapasztalatai rendkívül vegyesek, de lényegében a szakpolitikai értékelő elemzések (Tavistock 1999; EP 2008) is alátámasztják Putnam elméleti kutatásainak alaptézisét, mely szerint a horizontális kormányzási módszerek sikere jelentős mértékben függ a társadalmi, kulturális környezettől (Putnam-Leonardi-Nanetti 1993). Putnam és Rhodes szerint valójában nem növekedett a helyi erők hatalma, inkább csökkent az elszámoltathatóság, nőtt a fragmentáció. Claus Offe viszont úgy látja, hogy a tradicionális bürokráciák és közszereplők helyére lépő ,„parakormányzati” szereplők valóban képesek katalizátor szerepet betölteni a különböző szektorok között (Jones 1999). A modell előnyeit respektálva egyes vélemények szerint az átláthatóságot rontó elemek ellensúlyozhatóak az erős társadalmi kontroll intézményesítésével (Moss 2000), és természetesen a társadalmi tőke, a bizalom jelenléte ugyancsak a hálózatok erejét növelheti. A bizalmat éppen a hálózatok megkülönböztető sajátosságának tekintik a piachoz és a bürokra- 
tikus koordinációhoz képest, amely csökkenti a tranzakciós költségeket, megalapozza a koordinációt és stabilitást, tanulást és innovációt stimulál (Klijn 2010).

Kutatásunk szempontjából feltételezhető, hogy a város és környéke együttműködését, fejlesztését irányító rezsimek azonosítása során a felülről motivált, formalizált partnerségeknek a szerepe döntő jelentöségủ lesz, különösen egy olyan országban, ahol a fejlődés, fejlesztéspolitika forrásai elsősorban külsődlegesek, támogatások, amelyek az utóbbi években szinte kizárólag az uniós strukturális alapoktól érkeznek. Az ún. projektosztály jelenségével (Kovách 2008; 2009) azért indokolt foglalkozni, mert alkalmas lehet a kelet-európai társadalmi, gazdasági, kulturális különbségek kimutatására a nyugati (amerikai) társadalom és gazdaságfejlödés bázisán müködő fejlesztési rezsimek összetételéhez és szerepéhez képest.

\section{Szervezet-elmélet}

Hasonlóképpen relevánsnak tekinthető az Ostrom (2005) által kidolgozott ún. intézményi elemzési és fejlesztési modell (IAD), amelynek fókuszában az ún. akciótér áll. Az akciótérben azonosítják a releváns szereplöket, ezek egymáshoz való viszonyát, interakcióit, az alkalmazott, illetve érvényesülő szabályokat, $s$ az ezekre ható külső környezetet, annak legfontosabb sajátosságait. Az akciótér, a rész és egész viszonyának kijelölése a sokszektorú és sokszintü, hierarchikus és horizontális módon kapcsolódó elemek/intézmények kusza szövetéből, egyáltalán nem könnyü feladat. Ostrom szerint segítséget nyújt a holon fogalma, amelyet Koestler vezetett be annak érdekében, hogy kapcsolatot teremtsen rész és egész között. A holon, a rész és egész elemeiből kialakított alcsoport, melyen belül egységesen érvényesülő szabályok mentén történik a kormányzás. A hierarchikus rendszerek nem csak elemi jelentőségü egységeket/szinteket foglalnak magukba, hanem ágazatokra bonthatóak, melyek csomópontjait a holon alkotja, ezeken keresztül az ágak kommunikálnak egymással (Ostrom 2005, 11). A holon segítségével tehát kijelölhető a vertikális és hierarchikus intézményi konglomerátumból egy egység, amely belső kohéziót mutat, és ezzel elemezhetővé válik.

Az Ostrom által kidolgozott akciótér, illetve IAD modell abban segít, hogy elemzésünk egységét jól válasszuk ki, s benne a szereplők közötti interakciókat az öszszekötő szabályok (pozíciós, határ, választási, aggregációs, információs, kiegyenlítési és kiterjedési szabályok [Ostrom 2005, 191]) azonosítása alapján értelmezhessük, s kalkuláljunk a szereplők cselekvéseinek kimeneteleivel.

Kutatásunk szempontjából tisztázandó, hogy a városi kormányzás térbeli kapcsolódásait hogyan elemezhetjük, tekinthetö-e a városi tér akciótérnek, hol vannak a földrajzi és intézményi határai, kik a valós részszereplők, egységek stb. E kérdések megválaszolásához az IAD modell alkalmasnak ígérkezik. Annyi bizonyos, hogy a városi irányítási rezsimek túllépnek a közhatalmi szférán. Ugyanakkor vélhetően az egyes városokban, városi terekben, amelyeket összehasonlító igénnyel elemzünk majd, különbözö körökre, szereplőkre terjed ki a kapcsolatrendszer attól függően, hogy a város gazdasági szerkezete, fejlödési pályája, kormányzási filozófiája, civil szövete stb. milyen. 


\section{A neoweberi fordulat}

Az elméleti, módszertani alapok lefektetése során számolni kell azonban azzal is, hogy a legfrissebb folyamatok, a pénzügyi-gazdasági válság és a nyomában fellépő gazdasági, társadalmi feszültségek nyomán mind a rezsim, mind a governance modell kritikája felerősödik. A neoliberális gazdaság és kormányzás felfogás kudarca hatására a horizontális partnerségi és piaci elemekkel operáló „governance” kritikája elvezethet a klasszikus képviseleti demokrácia és a bürokrácia neoweberiánus visszatéréséhez (G. Fodor-Stumpf 2008). Az egyre népszerübb modell leszámol az NPM-hez füzött illúziókkal, visszakövetelve a bürokratikus közigazgatás rendjét, átláthatóságát. De hasonlóképpen elbizonytalanodás érzékelhető önmagában a decentralizáció hatékonysági, agglomeratív előnyeit, illetve a jóléti állam funkcióit, s a regionális polarizációt illetően is. Az egyik véleménycsoport szerint a decentralizáció akadályozhatja a jóléti állam funkcióinak méltányos, egységes és gyors gyakorlását, míg a másik csoport azt hangsúlyozza, hogy a decentralizáció nem feltétlenül vezet különböző közpolitikai gyakorlathoz, mint inkább politikai legitimációs funkciót tölt be a döntéshozatal polgárokhoz közelítésével. A baj csak az, hogy egyik tábor sem rendelkezik igazán evidenciákkal a decentralizáció előnyei és hátrányai tekintetében (Banting-Costa-Font 2010).

A neoweberiánus megközelítés nem csak a centralizáció/decentralizáció normatív értékként kezelése ellen lép fel, hanem újraértékeli a partnerség jelszava alatt exkluzív hálózatokba szerveződő elittel szemben (Olsson 2001) a képviseleti és részben a részvételi demokrácia előnyeit, vagy legalább kiegyensúlyozottabb arányok tartására és az elszámoltathatóság garantálására int. Ugyanakkor a váltás nem akarja a korábbi mintegy két évtized törekvéseit teljes egészében megtagadni, hanem igyekeznek megszüntetve megőrizni a korábbi korszak bizonyos előnyeit is: a szervezetek nyitottságát, a diszkurzív/deliberatív elemeket, az eredményérdekeltséget, költségérzékenységet (Dreschler 2009, 13).

Az erősödő állam, közhatalom szükségszerủen centralizációval jár együtt, ami meggyengítheti a kormányzás horizontális elemeit, működési módszereit. A hierarchia a térbeli kormányzásban újra a szintek megerősödéséhez vezethet, a legitimációs és gazdasági válság pedig elbizonytalanítja a közhatalmi szektoron kívüli hálózatok pozitív hatását. E jelenségekkel, új kérdésekkel számolva kell tudni kijelölni kutatásunkban a rezsim megközelítés határait.

\section{A kormányzási terek átalakulása, a városi hálózatok helye}

\section{Város a területi kormányzati rendszerben}

Mint említettük a bevezetőben, kutatásunk a városi terek intézményesítését szolgálja, ezért értelemszerűen megközelítésünk nem fókuszálhat pusztán az intézményekre, szereplőkre és ezek hálózataira, hanem ehhez értelmezési keretül szolgálnak 
a térbeli dimenziók. A kormányzási modellek és korszakok egyik fontos dimenziója a térbeliség, az átalakuló közpolitikai, kormányzási modell gyakran a térbeli léptékek váltásához (rescaling) vezet. A szakirodalom rescaling-nek nevezi azt a reformot, folyamatot, amelynek eredményeként megváltozik a közigazgatás térbeli szerkezete, a közigazgatási egységek mérete. De tágabb értelemben azt a folyamatot is ezzel a terminológiával illetik, amely bizonyos (társadalmi, gazdasági stb.) tényezők térbeli kiterjedésének, kereteinek az átalakulásához vezet, továbbá, amikor átstrukturálódik a hatalom szerkezete, a hatalom ,átugrik” egyik szintről a másikra (Swyngedouw 2000). A rescaling tehát szorosan összekötődik a kormányzás új gyakorlatainak, szerkezetének a kialakulásával, egyszerre jelenthet formai (földrajzi) és tartalmi változást (Guilani 2006).

Az utóbbi évtizedekben a területi közigazgatás térbeli léptéke, a szintek száma és mérete tekintetében és hatalomszerkezeti értelemben is jelentős változások következtek be Európában. Míg a hetvenes években elsősorban az alapszint konszolidálására került sor egyesítve vagy társulásba terelve a kisebb méretủ helyi önkormányzatokat, addig a kilencvenes évektől a középszintủ kormányzási szint reformja volt különösen jellemző, vagy földrajzi, vagy hatalompolitikai, vagy mindkét értelemben (Pálné Kovács 2005). A reformokat nagyon gyakran a méretgazdaságosság alapvetően neoliberális közgazdasági megközelítése alapozta meg, azt feltételezve, hogy a nagyobb középszintủ kormányzati/önkormányzati lépték nagyobb hatékonyságot eredményez a gazdaságfejlesztésben és különösen a drágább vonalas, technikai infrastruktúrával operáló intézmények, létesítmények keretében nyújtott közszolgáltatások terén. Nagyon gyakran azonban a reformok mozgatórugói hatalompolitikai jellegủek voltak, valamifajta föderalizálást megcélozva, többnyire etnikai, kulturális konfliktusok megoldását keresve, vagy történelmi tradíciókra hivatkozva. Ezekhez a regionalizációs jelenségekhez kapcsolódik leginkább a Keating nevéhez füződő új regionalizmus eszméje, mozgalma, amely a hatékonyságot összekapcsolja a demokratikus decentralizációval, a helyi társadalom, gazdaság mozgósításával járó előnyökkel, illetve az európai integrációt támogató nagyobb legitimációval (Keating 2004).

Nem hanyagolható el, bár az eredmények reális mérlegelése tükrében nem is túlozható el az Európai Unió kohéziós politikájának hatása a középszintủ kormányzás tereinek és szereplöinek átalakulásában. A szintek és léptékek közpolitikák hatékonyságára gyakorolt szerepét illetően elbizonytalanodás érzékelhető az Európai Unió szintjén is. Ha az uniós kohéziós politikát alávetjük az ún. szubszidiaritási tesztnek, egyformán súlyos érvek hozhatók fel az európai szintű szerepvállalás, mint a nemzeti mellett (Begg 2008). Ugyanakkor abban egyetértés mutatkozik, hogy az uniós szerepvállalás mindenképpen szélesítette a résztvevők körét, különösen a régiók bevonását.

Az uniós regionális politika különböző ciklusaiban különböző kormányzási sajátosságok váltak jellemzővé a nemzeti struktúrákban:

- A hetvenes évektől a nyolcvanas évek végéig erős nemzeti centralizáció volt jellemzö, s az alapvetően újraelosztási döntésekhez a központi kormányok nem vontak be sem vertikális (területi) sem horizontális (szektorális) partnereket. 
- A regionális decentralizáció a kilencvenes évtizedben következik be a „régiók Európája" virágkorában, s ezt kísérte a profit és nonprofit szektorral való partnerségek kiépítése. Ugyanebben az időszakban kezdődik a kohéziós politika technikai, statisztikai kereteiként kijelölt ún. NUTS 2 régiók hatalommal, forrásokkal, politikai legitimációval való feltöltése.

- Az ezredfordulót követően azonban megindult egyfajta visszarendeződés a korábbi regionális decentralizációhoz képest. A 2000-rel indult programozási periódusban az osztott felelősség elve alapján a nemzetállami kormányok, megnőtt felelősségükre hivatkozva, nemcsak a Bizottsággal szemben szereztek nagyobb mozgásteret, hanem sok országban a régióikkal szemben is, amennyiben saját kezükbe vették az alapok feletti rendelkezést, s a regionális szintek inkább a végrehajtási feladatokat kapták.

- Különösen markáns centralizáció vált jellemzővé a 2004-et követő bővüléssel. Az új tagállamok strukturális alapokat kezelő intézményi modellje szélsőségesen centralizált (Bachtler-McMaster 2008). A regionalizáció európai tapasztalatai tekintetében a kelet-európai reformok inkább kudarcokat hoztak, hozzájárulva az „új regionalizmussal” kapcsolatos általános elbizonytalanodáshoz (Elias 2008; Scott 2009). Kérdés, hogy a dominánsabb központi állami szerepvállalás milyen hatással lesz a horizontális partnerségekre, amelyek elsősorban területi és helyi szinteken mutattak igazi hatékonyságot?

Kutatásunk szempontjából a 2007-2013 közötti programozási periódus hangsúlyeltolódásai különösen relevánsak. Mint tudjuk, az uniós kohéziós politika összekapcsolódott a versenyképességi célokkal, ami a korábbi hátrányos helyzetü NUTS 2 régiókhoz képest a városi térségek támogatását is lehetővé tette. A policentrikus városfejlesztés, a városi hálózatokra alapozott regionális fejlesztés modellje lényegében nem új Európában. Az egyes országok (különösen Németország, Franciaország, Nagy-Britannia) fejlesztéspolitikája már a hetvenes évtizedben is jórészt ezt a filozófiát követte. A kilencvenes években született európai fejlesztéspolitikai dokumentum, az ESDP, illetve az EU által finanszírozott ESPON program még inkább hangsúlyozta a városi hálózatok térformáló szerepét a fejlesztéspolitikában és a közszolgáltatások megszervezésében.

A strukturális alapok jelenlegi programozási periódusában bekövetkezett hangsúly, illetve paradigmaváltás azonban ennek ellenére még az uniós apparátusokon belül is feszültségeket okozott, mint ahogy az egyes tagállamok kormányzati szereplői körében is bizonytalanság forrása volt, hogyan kell beépíteni a városi dimenziót a strukturális alapok felhasználási rendjébe. Nem véletlen, hogy a közösségi stratégiai iránymutatások kidolgozását megelőzően sokat foglalkoztak azzal, hogyan illeszthető a városok megerősített szerepe a kohéziós politikába (harmadik kohéziós jelentés, Európai Parlament állásfoglalása a városi dimenzióról a növekedés kapcsán, a Bizottság munkadokumentuma a kohéziós politika és a városok címmel, Bristoli kezdeményezés, városok fóruma, tematikus konferencia Barcelonában, ESPON stb.). 
Az Európai Bizottság egy dokumentuma már 2006-ban felhívta a figyelmet a városi dimenzió felértékelődésére, javasolva a tagállamok, régiók és városok partnerségének kiépítését, a városi agglomerációk integrált városfejlesztési stratégiáinak kidolgozását. Az Európai Regionális Fejlesztési Alapról szóló hatályos ET-EP rendelet is 8. cikkében kiemeli a városi dimenziókat, hangsúlyozva az integrált stratégiák szükségességét. Külön felhívták a figyelmet arra a lehetőségre, hogy a tagállamok átadhatják a városoknak az operatív programok keretében a fejlesztési programokra szánt források kezelését.

A Régiók Bizottsága maga is szorgalmazta, hogy a közösségi stratégiai iránymutatások ne csupán a területi sajátosságok keretébe illessze a város dimenziót, hanem vezessen be egy negyedik prioritást, amely a városokra és a városi régiókra koncentrált volna. A Régiók Bizottsága arra is felhívta a figyelmet, hogy a városok dimenzióját valamennyi közösségi politikában érvényesíteni kellene. A szociális és civil párbeszédhez hasonlóan, területi párbeszédet kezdeményezett a városok új szerepéről mind európai, mind a tagállamok dimenziójában.

A kohéziós politikai irányelveket elfogadó Európa tanácsi határozat, ha nem is negyedik dimenzióként, de deklarálta, hogy fontos a kohéziós politika területi dimenziója, az iránymutatásoknak figyelembe kell venniük a városi és a vidéki területek beruházási igényeit. A kohéziós politika területi dimenziója fejezetben külön pontot szentelt a városoknak, megemlítve a klaszterekbe rendezés révén megvalósuló fejlesztéseket, vagy a városi hálózatképződést. Az irányelvek is hangsúlyozza, hogy a városi programok végrehajtása ráruházható a városokra, kiemelve az integrált megközelítés szükségességét. A városi reneszánsz tehát lényegében megerősítést nyert az uniós kohéziós politikában is, bár a kezdeti lelkesedés ellenére a városi szerepvállalás önálló felhatalmazással már lényegesen szerényebb. A területi kohézióról 2008-ban kiadott zöld könyv, majd a Barca és Samecki-féle jelentések, vagy éppen a funkcionális nagyrégiók (Balti-Duna) megjelenése azonban arra utal, hogy a kohéziós politika jellemző beavatkozási terei tekintetében még korántsem tisztult le a kép, így a városok, városi hálózatok szerepe sem.

Persze a zavarok nemzetállami szinten legalább ennyire jellemzőek, nem csupán az uniós kohéziós politikai váltás nyomán, hanem ettől függetlenül is. Mint említettük, a városok és városhálózatok térformáló szerepére a területi közigazgatás-szervezés még csak féloldalas, kísérleti jellegü válaszokat adott (Sýkora-Muliček-Maier 2009). A tudomány adóssága sem kisebb. Tanulságos lehet az a vita, ami az Egyesült Királyságban zajlik a városrégiókról (Lord 2009). A városrégiókban létrehozott különböző intézményi újításokkal kapcsolatban megfogalmazódott szkepticizmus abból származik, hogy az utóbbi évtizedekben központi kormányzati szintről meglehetősen hektikusan kezdeményezett területi reformok az új regionalizmustól, új lokalizmustól a városrégiókig, az intézményi újítások (ügynökségek, társaságok, partnerségi fórumok) tényleges hatásaival, előnyeivel (például a gyakran hangoztatott nemzeti versenyképességre), hátrányaival lényegében alig foglalkoztak tudományos igénnyel. Erre javasolják a kritikai realista episztemológiát, mint módszertani kiindulópontot, amely számol azzal, hogy a felülről kezdeményezett reformok 
inkább értéktartalmúak, mint evidenciákon alapulóak, és hogy a váltakozó közpolitikák logikailag tagadják a megelőzőket. A tudományos szakértő és a politika kapcsolatrendszerét illető izgalmas tanulságon túl, miszerint a szakértőknek sokkal több tudományos, empirikus evidenciára van szüksége, mielőtt egy új politikát javasolnak (Cheshire 2006). A tényleges evidenciákhoz képest előreszaladó intézményesítés veszélyét szellemesen fogalmazza meg Lovering: ne a policy (farok) csóválja az elemzést (a kutyát) (idézi Harrison 2007, 316). Nagyon fontos továbbá megérteni az intézményi reformok útfüggőségét és kontextualitását. Az intézményi múlt mindig erősen korlátozza az újítások megvalósulását (Jessop 2002). A brit példához képest természetesen vannak olyan nemzetközi megoldások, ahol a városok térszervező szerepét már biztosabb alapokon intézményesítették (Németország, Franciaország, Olaszország stb.). Ennek ellenére nem állítható, hogy a területi közigazgatási modelleket a városi terek felértékelődése Európában totálisan megváltoztatta volna, különösen így van ez a kevésbé urbanizált Kelet-Közép-Európában (Sýkora-Muliček-Maier 2009). A városi kormányzásban nem is lehet addig konkrét reformokkal elöállni, amíg meg nem értjük a városi térben zajló folyamatokat, amelyek rendkívül komplexek, ön-magukban sem a közgazdasági-tértudományi, sem az igazgatás és politikatudományi evidenciák és elméletek nem segítenek.

A városi terek stabil és általános közigazgatási intézményesítése annak ellenére várat magára, hogy elemzések sokasága áll rendelkezésre a városok hálózatairól, hierarchiájáról európai (ESPON) és nemzeti léptékben is. A térgazdaságtan eredményei is jelentős elméletekkel járultak hozzá az új gazdasági terek megértéséhez (Benko 1997). Bár vannak olyan vélemények is, hogy az intézményi közgazdaságtan éppen a térbeli vonatkozásokkal adós, tehát szükség van új intézménygazdaságtani földrajz megteremtésére (Gertler 2010). A városi terek intézményesítésében tapasztalható „,késlekedés” oka egyrészt az, hogy e terek rendkívül dinamikusan változnak, s a változások hajtóerőinek köre és hatása csak részben tisztázott, illetve prognosztizálható, másrészt viszont az, hogy e dinamikus térkategóriát rendkívül nehéz beilleszteni a statikus rendszerü közigazgatásba, ráadásul ez nem is tehető meg a közigazgatási tér egészét lefedően. Ez utóbbi veszélyre hívja fel a figyelmet Herrschel, féltve a rurális, kevésbé felfüzött térségeket a kizárólag városi logikával történő kormányzástól (Herrschel 2009).

A rescaling típusú strukturális reform beavatkozás tekintetében tehát érthető az óvatosság. Kutatásaink kezdetén tehát arra hajlunk, hogy a rugalmasabb, lazább szervezeti megoldások jobban megfelelnek a városi terek szükségleteinek, ami egyben azt is jelenti, hogy hipotézisünk szerint a városi hálózati együttmüködések intézményesen nem alternatívái a szintszerü középszintü kormányzásnak. A mi kutatásunk számára annyi bizonyos, hogy az Ostrom-féle akciótér kijelölése során el kell hagynunk a város falait, mi több, az sem biztos, hogy a hivatalosan kijelölt agglomerációk lesznek a tényleges hálózati együttműködés földrajzi keretei. 


\section{A városi terek belső tagolódása}

A városi terek kormányzása szempontjából nem csak az a fontos, hogy e terek hogyan illeszkednek a területi közigazgatás, illetve a kormányzás általános rendszerébe, hanem az is, hogy milyen a viszony a város és környéke között.

A térbeli dimenziók bekapcsolása a helyi politika-elemzésekbe rendelkezik tudományos és módszertani előzményekkel. A korábbi fejezetekben érintett helyi közösségvizsgálatok hosszú ideig eltekintettek a város ökológiai/térbeli sajátosságaitól, majd az ökológiai aspektusok bekapcsolásakor is eleinte figyelmen kívül hagyták a szervezeti vonatkozásokat. Az ökológiai megközelítés a 20. század második felében a községszociológia egyik legjelentősebb paradigmájává vált. Park iskolájának Chicagóban folytatott vizsgálatai az emberi társadalom együttélési formáit szorosan összekapcsolták a földrajzi tér sajátosságaival. Amikor az ökológiai iskola az extra lokális kapcsolatok szervezeti következményeire is kiterjesztette elemzéseit, egy fontos dimenzióval bővült a helyi hatalmi struktúrák elmélete. Különösen Hawley lépett nagyot elöre, amikor az ökológia uralkodás koncepcióját alkalmazta a szervezeti viszonyok elemzése során is, rámutatva, hogy a település két „exportszektora” a gazdaság és a helyi kormányzat „külpolitikája”, azaz kifelé végzett érdekérvényesítő, kormányzó tevékenysége (Hawley 1968). Nyilvánvalóan a városi funkciók rendezik el a települések közötti hatalmi viszonyokat is. Lincoln véleménye szerint a helyi közösségekben a szervezeti uralkodás módja, formája az ottani funkciók típusának, valamint a funkcionális specializáció fokának függvénye lesz. A városban lévő szervezeti, irányítási központok irányítják az ágazati egységek működését, ezeken keresztül pedig a központi település uralkodik a 'csatlósok' fölött. A lokális és extra lokális uralkodás nem más, mint egyetlen folyamat - nevezetesen a hatalom és a források egy földrajzi keretben való koncentrációja (Lincoln 1977). Friedmann mutatja ki, hogy a magrégiók (központok) miközben az ellátásiirányítási rendszereket térben integrálják, egyben szervezeti függőséget kényszerítenek a perifériára, ami megjelenik a források elszívásában, az információs függöségben. A mag és a periféria közötti típusokat elemezve arra a következtetésre jut, hogy az optimális viszony az együttmüködés lenne, de ennek a feltételei sok esetben nem állnak rendelkezésre (Friedmann 1969).

A hatalom ökológiai szemlélete azonban még nem igazán hatja át az igazgatástudományi gondolkodást. A városok és környékük együttműködésének intézményesítése, mint említettük, ugyan sokféle modell szerint történik, felismerve, hogy alapvetően horizontális elemekkel lehet csak összekapcsolni közjogilag autonóm településeket és szereplőket. Ugyanakkor a valóságban a települések közötti kapcsolatrendszerek gyakran aszimmetrikusak, a mag (város) gazdasági, szociológiai, hatalmi fölénye tény, ami inkább akadálya, semmint elömozdítója a városi terek integrálásának, hálózatosodásának. Kutatásunk hipotézise szerint ezt a tényleges hatalmi szituációt oldhatná, de mindenképpen színesíti a városi kormányzás nem közhatalmi szereplőinek részvétele. 


\section{Városi kormányzási rezsimek a hazai viszonyok között - politikatudományi kérdésfeltevések}

Visszatérve a rezsim elmélethez, vajon a helyi hatalmi viszonyok, a helyi fejlesztési rezsimek elemzése mennyiben segíthet hozzá a városi terek kormányzásának modellezéséhez?

Nálunk a hálózatok, a településeket, régiókat átszövő sokszereplős rendszerek empirikus kutatására kevés példa akad. A viszonylag kisszámú hazai empirikus politikatudományi, politikai szociológiai elemzés sokkal inkább egy-egy jellemző szereplöt próbál elemezni országos, vagy kisebb reprezentatív minták alapján (BőhmPál 1983-1988; Pálné Kovács 1990; A. Gergely 1996; Horváth M.-Kiss 1996; Kákai 1996; Bódi-Bőhm 2000; Kunszt 2001; Bőhm 2006). Ennek egyik oka, hogy még kevésbé ismertük fel a ténylegesen helyi, komplex típusú kutatások jelentőségét, mint ahogy a helyi politikusok, önkormányzatok által megrendelt közvélemény-kutatások is leginkább a választói magatartásra kíváncsiak, kevésbé arra, hogy általánosan értékeljék a helyi kapcsolatrendszereket. Az erösen „vertikális” szemlélet, illetve a helyi társadalom , „célcsoportként”, vagy legfeljebb választóként kezelése végül is kompatibilis a hazai politikai kultúrával és a központosított hatalmi modellel.

Feltételezésünk szerint a magyar városi kormányzás sem szabályozott modelljét, sem működési gyakorlatát tekintve nem képes befogadni a rezsim elmélet logikáját. Ez nem azt jelenti, hogy a városházi döntésekben Magyarországon ne játszana szerepet a térségben, városban müködő gazdasági és egyéb szereplők bizonyos köre, csoportja. Ez a befolyás azonban nem valamiféle szilárd és kollektív fejlesztési szövetségen keresztül, hanem a dominanciáját megőrző helyi (központi) közpolitikai „rendszer-rezsim” közvetítésével, tehát szelektíven érvényesül. Azt is feltételeznünk kell sajnálatos módon, hogy a szelektivitás esetenként korrupcióra épül. Ennek alapján az is feltételezhető, hogy a gazdaság bizonyos szereplöi számára fontos agglomerációs előnyök érvényesítése a városvezetéssel szemben ugyancsak korlátokba ütközik. Ha ugyanis a gazdaság- és városfejlesztésben nem múködnek tartós fejlesztési koalíciók, akkor adott esetben a bezárkózásra hajlamos városházi politika a gazdaság agglomerációs együttműködéshez füződő érdekeit negligálja, és megfordítva, a városháza sem képes a gazdaság szereplőit telephely-választási döntéseiben, „térstratégiáiban” befolyásolni. Az együttmüködés hiánya sok tényezőből eredhet, az egészen soft kulturális különbségektől, kormányzási stílusoktól, a bizalom jelenlététől a közjogi, finanszírozási szabályokig, a jelenlévő gazdasági elit helyi kötődésétől a tevékenységi profiljáig, piaci helyzetéig, s természetesen újra meg kell jegyezni a korrupció szerepét is. Remélhetően kutatásaink rávilágítanak majd a legfontosabb magyarázó tényezőkre.

Nálunk a közjogi és elosztó hatalommal rendelkezö önkormányzatok szerepe a hálózatokon belül azért feltételezhető hangsúlyosnak, mert szerepük nem csak a közszolgáltatásokban, hanem az infrastruktúra- és gazdaságfejlesztésben is domináns 
nem csak, mint beruházók, intézmények tulajdonosai, működtetői, hanem mint a fejlesztési források kedvezményezettjei.

$\mathrm{Az}$ érem másik oldalán a lehetséges partnerek forráskészlete lényegesen gyengébb. Magyarországon a települések többségében fejletlen a civil társadalom, a gazdasági szervezetek ereje differenciált, területileg is rendkívül egyenetlenül oszlanak meg, ezért feltételezhető, hogy a hálózatokban sem képesek erős, tartós pozíciót szerezni. Különösen fontos lehet megvizsgálni a külföldi tulajdonban lévő, illetve multinacionális vállalkozások lokális kormányzattal és a beszállítói hálózatokkal való együttmüködését. Feltételezzük, hogy a gazdaság szereplői közötti kapcsolatok hiánya, helyhez kötődésének alacsony foka miatt nem képesek tartós szövetségekre, ugyan szervezeti és személyes érdekeiket alkalmi szövetségekben is érvényesíthetik, nem képesek azonban a településpolitika meghatározó résztvevőivé válni. A szervezett civil társadalom, s az egyén helyi politikai befolyása, hálózatokba épülése intézményes és kulturális garanciák hiányában szintén nem jellemző.

Különösen az Európában lezajlott integrációs folyamatok nyomán a helyi kormányzásban a méret és a demokrácia összefüggésrendszere újra és újra felmerül (Goldsmith-Rose 2002), tehát figyelembe kell vennünk majd, hogy a városok mérete önmagában magyarázó tényező. Valószínü, hogy a kutatásunkba bevont nagyobb, régióközpont városok helyzete differenciált, mint ahogy gazdasági szerkezete, kondíciója is. Különösen más a helyzet a fővárosban, amely mérete, fejlettsége folytán már valódi fejlesztő koalíciók kerete lehet, mint ahogy agglomerációs kapacitása, kapcsolatrendszere is nagyságrendekkel és minőségileg is különbözök a többi magyar nagyvároshoz képest. A tervezett kutatás fókusza és a kiválasztott minta okán azonban a fővárost, mint metropoliszt nem fogjuk érinteni.

A helyi hálózatok világával kapcsolatos hipotéziseink szerint nálunk a helyi kormányzás arénája nem csak szereplőit, hanem mechanizmusait tekintve is szegényesebb a fejlett nyugati urbánus terekben azonosítottakhoz képest. A közszektor dominanciája jelentős következményekkel jár a hálózatok szerkezetére, működési mechanizmusaira nézve, mégpedig azzal, hogy a közjogi logika és korlátok erőteljesen központosítják, illetve láthatatlanná teszik a hálózatokat.

Nálunk is érzékelhető a ,politikai vállalkozók” csoportjának, különösen az erős, karizmatikus, funkciókat halmozó helyi polgármestereknek a megjelenése és domináns szerepe (Jouve-Lefévre 2002). A helyi képviselőtestületbe bekerült politikai szereplők, a hivatali vezető adminisztrátorok és a hozzájuk kapcsolódó párt, civil és gazdasági klientúrák képesek esetenként a döntéshozási mechanizmusban vétó hatalmat gyakorolni, helyzetük az ellenzéki és kormányzó pozíció függvényében váltakozik. Feltételezhető, hogy a saját testületével és hivatalával szemben erős befolyást, a helyi társadalomban tartósan népszerüséget birtokló polgármester a helyi hálózatok stabil és domináns szereplője, akinek pozícióját személyes klientúra is támogatja. A polgármester ereje, egységesítő funkciója, populista kommunikációs stratégiája különösen a biztonságra vágyó városi lakosság körében eredményezhet gyakran erőteljes centralizációt a helyi politikában (Judd 2000). 
A magyar újraelosztási viszonyok, a fejlesztéspolitika forrásrendszere a polgármestert e hálózatokon belül érthető módon nagyon gyakran juttatja kulcspozícióba, hiszen képes az előnyök, javak cseréjére. A polgármesterek körében végzett összehasonlító kutatás szerint a magyar polgármesterek háromnegyede számára az alapvető elérendő cél az infrastruktúra és a közlekedés fejlesztése, kétharmaduk számára pedig a vállalkozások gyarapítása is. Más kérdés, hogy ezt a gazdaságfejlesztő szerepfelfogást végül is milyen hatékonysággal tudják érvényesíteni (Mezei 2006). A magyar polgármesterek értékrendjében a posztmateriális javak, mint például a kultúra, sokkal hátrább szerepelnek, mint például a cseh polgármesterekében. Szerepfelfogásuk egyrészt egyfajta „hiperaktivitásra” utal, amennyiben a felsorolt 16 feladatkörből tizenkettőt nagyon fontos személyes feladatnak tekintettek. A legfontosabb feladataik közé sorolták a külső erőforrások önkormányzatba vonzását, a külvilággal való kapcsolattartást, a helyi polgárok segítését, ami lényegesen kevésbé volt jellemző a nyugateurópai polgármesterek szerepvállalására (Tocqueville RC 2004).

Önmagában a személyiség teljesítménye nem elegendő ugyan a jelenség megértéséhez, ugyanakkor a személyiség, vezetési stílus, illetve stratégia nem elhanyagolható. Egy amerikai nagyváros kiemelkedő személyiségű polgármesterének teljesítményét elemző tanulmány hangsúlyozza, hogy a személyiség szerepe éppen akkor fontos, amikor a vezető akaratának érvényesülését sok tényező akadályozza, mégis képes változást elérni. Az amerikai polgármester pozíciója legendásan erős, gyakran törekszik magasabb politikai pozíciók megszerzésére is, igazán azonban akkor hatékony, ha akarata érvényesítése mellett képes a polgárokat is mozgósítani (Stone 1995).

A polgármester és a hozzá kötődő önkormányzati szervezeti egységek meghatározó szerepéből következik, hogy nálunk a polgármestert adó pártok, s a személyéhez füződő központi kormányzási kapcsolatok vélhetően erősebben érvényesülnek, mint a személyes pozíciókészlet és kapcsolatrendszer.

Ami a hálózatok térbeli kiterjedtségét, a városi kormányzás térbeli, vagy inkább extra lokális meghatározottságát illeti, azt feltételezzük, hogy a horizontális, agglomeratív kapcsolatrendszerek kevésbé jellemzőek a vertikálisakhoz képest. Ennek alapvető okát a magyarországi kormányzati rendszer erős centralizáltságával magyarázzuk. A decentralizáció mértéke három lényegi tényezőn múlik (Pickvance 1997):

- a központi és területi, helyi szintek közötti kapcsolatok minőségén, a helyi szervek szervezeti autonómiájának mértékén;

- a helyi szervek hatásköri felhatalmazásán, funkcióinak jelentőségén;

- a funkciók gyakorlásához rendelt források mennyiségén, a gazdálkodás szabadságán.

E tényezők közül a második tényezőcsoport a magyar önkormányzatok esetén is teljesül, míg az első és harmadik csak jelentős korlátokkal. Miközben a magyar önkormányzati szabályozás közjogi értelemben jelentős szervezeti autonómiát biztosít, a központi és helyi kapcsolatok minősége inkább paternalista jellegü, amit éppen a müködéshez, mozgástérhez szükséges források hiánya magyaráz. 
A decentralizáció előnyei között szokás megemlíteni, hogy több esélyt ad helyi gazdaságfejlesztési kezdeményezésekre, a helyi erőforrások hatékonyabb kihasználására, optimálisabb forrás-allokáció érhető el, és erősíthető a helyi kormányzás helyi problémakezelő kapacitása, s csak az erős helyi kormányzatok képesek erősíteni a helyi civil társadalmat, valóságosan pluralizálva a helyi politikát, hozzájárulva a helyi identitás, közösségi kohézió megőrzéséhez (Work 2001; Barlow-Wastl-Walter 2004).

A magyar önkormányzati rendszer ellentmondása, hogy csak közjogilag decentralizált, ezért a decentralizáció sok elönye nem képes hasznosulni, nem csak a fenti funkciók vonatkozásában, hanem a települési önkormányzatok közötti együttműködés formálásában sem. A centralizáció dominanciája jól érzékelhető abban, hogy napjainkra a városok térszervező aktivitása helyett a központi kormányzat által kínált vagy inkább előírt „,horizontális” formák váltak a város és környéke együttmüködésének keretévé. A hazai kistérségi rendszer müködési tapasztalatai azt mutatják, hogy a kormányzati pénzügyi ösztönző rendszerek hatására ugyan megindult a közszolgáltatások racionálisabb térbeli keretekbe történő átszerveződése, de ez a folyamat a legkevésbé érintette a városokat, már csak azért is, mert a térségi integráció sokkal inkább az alapszintü, mint a középszintű szolgáltatások terén zajlik. A kistérséget uraló nagyváros ambivalens viselkedését jól érzékelteti egy aprófalú polgármesterének véleménye: „Míg a kistérség munkaszervezete érzékelni tudja a kistérséget és annak tagjait, addig a pécsi városházába soha nem lesz betekintésünk, de befolyásunk még kevésbé." (Somlyódyné Pfeil 2008a, 277)

Összegezve kutatásunk induló hipotéziseit, azt feltételezzük, hogy a hazai közjogi, politikai, gazdaságpolitikai, kulturális környezet nem igazán nyújt optimális feltételeket a horizontalitást, partnerséget igénylő rezsim-szerü városi kormányzáshoz, miközben az iskola egyes képviselői a középszintű kormányzatok, régiók számára is alkalmazhatónak vélik (Sagan 2009). A magyar városok kormányzását a közhatalmi szereplök uralják, a városi tereket, vonzáskörzeteket, agglomerációkat, kistérségeket paradox módon szintén, miközben a rájuk háruló egyre fontosabb közszolgáltatási és gazdaságfejlesztési funkciókkal egyedül egyre kevésbé tudnak megbirkózni.

\section{Jegyzet}

${ }^{1}$ Az agglomerációk intézményesítésének sajátos kérdései a közigazgatási struktúrán innen és túl című, 81789. sz. OTKA kutatás, témavezető Somlyódyné Pfeil Edit.

\section{Irodalom}

Aiken, M.-Mott, P.E. (eds.) (1970) The Structure of Community Power. Random House, New York.

A. Gergely A. (1996) Lokalitás, kisvárosiság, elit-státusz. - Utasi Á.-A. Gergely A.-Becskeházi A. (szerk.) Kisvárosi elit. MTA PTI, Budapest. 105-125. o.

Amin, A.-Thrift, N. (1995) Institutional issues for the European regions: from markets and plans to socioeconomics and powers of association. - Economy and Society. 1. 41-66. o.

Bachtler, J.-McMaster, I. (2008) EU cohesion policy and the role of the regions: investigating the influence of Structural Funds in the new member states. - Government and Policy. 2. 398-428. o. 
Banting, K.-Costa-Font, J. (2010) Decentralization, welfare, and social citizenship in contemporary democracies. - Environment and Planning C. 3. 381-389. o.

Barlow, M.-Wastl-Walter, D. (eds.) (2004) New Challenges in Local and regional Administration. Ashgate, Aldershot.

Begg, D. et al. (1993) Making Sense of Subsidiarity: How Much Centralization for Europe? Centre for Economic Policy Research, London.

Begg, I. (2008) Subsidiarity in Regional Policy. - Gelauff, G.-Grilo, I.-Lejour, A. (eds.) Subsidiarity and Economic Reform in Europe. Springer, Berlin, Heidelberg. 143-157. o.

Benko, G. (1997) A regionális fejlődés útjai: globálistól a lokálisig. - Tér és társadalom. 2. 1-16. o.

Berg, van den, L.-Braun, E.-van der Meer, J. (1997) The organising capacity of metropolitan regions. Environment and Planning C. 3. 253-273. o.

Bódi F.-Bőhm A. (szerk.) (2000) Sikeres helyi társadalmak Magyarországon. Agroinform Kiadóház, Budapest.

Bovaird, T.-Löffler, E.-Parrado-Díez, S. (eds.) (2002) Developing Local Governance Networks in Europe. Nomos, Baden-Baden.

Böhm A. (szerk.) (2006) A helyi hatalom és az önkormányzati választások Magyarországon 1990-2002. MTA PTI, Budapest.

Bőhm A.-Pál L. (szerk.) (1983-1988) Helyi társadalom I-VI. MSZMP KB Társadalomtudományi Intézet, Budapest.

Börzel, T.A. (1998) Organizing Babylon: On the Different Conceptions of Policy Networks. - Public Administration. 76. 253-273. o.

Cheshire, P. (2006) Resurgent cities, urban myths and policy hubris: what we need to know. - Urban Studies. 8. 1231-1246. o.

Clark, T.N. (2003) Globalisation and Transformation in Political Cultures. - Hambleton, R.-Savitch, H.Stewart, M. (eds.) Globalism and Local Democracy. Challenge and Change in Europe and North America. Palgrave Macmillan, Houndmills. 67-91. o.

COM (2006) A bizottság közleménye a tanácsnak és az Európai Parlamentnek. Kohéziós politika és a városok: a városok és az agglomerációk hozzájárulása a régiók növekedéséhez és foglalkoztatottságához. http://ec.europa.eu/regional_policy/consultation/urban/com_2006_0385_hu.pdf

Dahl, R.A. (1961) Who Governs? Democracy and Power in an American City. Yale University Press, New Haven, C.T.

De Vries, M.S. (2002) Interactive Policy-Making in Local Governance: An International Comparison. Bovaird, T.-Löffler, E.-Parrado-Díez, S. (eds.) Developing Local Governance Networks in Europe. Nomos, Baden-Baden. 91-107. o.

Dreschler, W. (2009) Towards a Neo-Weberian European Union? Lisbon Agenda and Public Administration. - Halduskultuur. 10. 6-22. o.

Duncan, S.S.-Goodwin, M. (1988) The Local State and Uneven Development: Behind the Local Government Crisis. Policy Press, Cambridge.

Elias, A. (2008) Introduction. Whatever happened to the Europe of Regions? Revisiting the Regional Dimension of European Politics. - Regional and Federal Studies. 5. 483-493. o.

EP (2008) Governance and partnership in regional policy. European Parliament IP/B/REGI/FWC/2006Lot05-C02-SC02. PE397.245

Friedmann, J. (1969) A General Theory of Political Development. University of California, Los Angeles.

Gertler, M.S. (2010) Rules of the Game: The Place of Institutions in Regional Economic Change. Regional Studies. 1. 1-17. o.

G. Fodor G.-Stumpf I. (2008) Neoweberi állam és jó kormányzás. - Nemzeti Érdek. 7. 5-27. o.

Giguére, S. (2002) Enhancing Governance Through Partnerships. - Bovaird, T.-Löffler, E.-ParradoDíez, S. (eds.) Developing Local Governance Networks in Europe. Nomos, Baden-Baden. 217-231. o.

Goldsmith, M.-Rose, L. (eds.) (2002) Size and democracy. - Government and Policy. 6. thematic issue.

Grote, J.R.-Gbikpi, B. (eds.) (2002) Participatory Governance. Political and Societal Implications. Leske+Budrich, Opladen.

Guilani, E. (2006) The Rescaling of Governance in Europe: New Spatial and Institutional Rationales. Guest editorial. - European Planning Studies. 14. 881-905. o.

Hambleton, R.-Savitch, H.-Stewart, M. (2003) Globalism and Local Democracy. Challenge and Change in Europe and North America. Palgrave Macmillan, Houndmills.

Harding, A. (1999) North American Urban Political Economy, Urban Theory and British Research. British Journal of Political Science. 29. 673-698. o.

Harrison, J. (2007) From competitive regions to competitive city-regions: a new ortodoxy, but some old mistakes. - Journal of Economic Geography. 3. 311-332. o. 
Hawley, A.H. (1968) Human ecology: A Theory of Community Structure. Ronald, New York.

Heclo, H. (1972) Review article: Policy analysis. - British Journal of Political Science. 2. 83-108. o.

Heinelt, H.-Wollmann, H. (Hrsg.) (1991) Brennpunkt Stadt. Stadtpolitik und lokale Politikforschung in den 80 er und 90er Jahren. Birkhäuser Verlag, Basel, Boston, Berlin.

Heinelt, H. (2002) Civic Perspectives on a Democratic Transformation of the EU. - Grote, J.R.-Gbikpi, B. (eds.) (2002) Participatory Governance. Political and Societal Implications. Leske+Budrich, Opladen. 97-118. o.

Heinze, R.-Volezkow, H. (1991) Regionalisierung der Strukturpolitik in Nordrhein-Westfalen. Politische Vierteljahresschrift. 22. Sonderheft. 461-477. o.

Herlyn, U.-Schweitzer, U-Tessin, W.-Lettko, B. (1982) Stadt im Wandel. Frankfurt/Main, Campus Verlag.

Herrschel, T. (2009) City regions, polycentricity and the construction of peripheralities through governance. - Urban Research\&Practice. 3. 240-250. o.

Horváth M. T.-Kiss, J. (szerk.) (1996) Aréna és otthon. Politikai Tanulmányok Intézete Alapítvány, Budapest.

Jessop, B. (2002) Time and space in the globalization of capital and their implications for state power. Rethinking Marxism. 1.97-116. o.

Jouve, B.-Lefévre, Ch. (eds.) (2002) Local Power, Territory and Institutions in European Metropolitan Regions. Frank Cass, London.

Jones, M (1999) New Institutional Spaces. Jessica Kingsley - Regional Studies Association, London.

Judd, D. (2000) Strong Leadership. - Urban Studies. 5/6. 951-963. o.

Judge, D.-Stoker, G.-Wolman, H. (eds.) (1995) Theories of Urban Politics. Sage, London.

Jung, T. (2010) Policy newtworks: theory and practice. - Osborne, S (ed.) The new public governance? Routledge, London, New York. 351-365. o.

Kákai L. (1996) Egy nagyvárosi önkormányzat müködési mechanizmusai. - Horváth M. T.-Kiss, J. (szerk.) (1996) Aréna és otthon. Politikai Tanulmányok Intézete Alapítvány, Budapest. 277-331. o.

Katz, B (ed.) (2000) Reflections on Regionalism. Brooking Institution Press, Washington DC.

Keating, M. (1991) Comparative Urban Politics. Edward Elgar, Aldershot, Hants.

Keating, M. (1993) The politics of economic development. - Urban Affairs Quaterly. 28. 373-396. o.

Keating, M. (ed.) (2004) Regions and Regionalism in Europe. An Elgar Reference Collection, Cheltenham.

Kearns, A.-Paddison, R. (2000) New Challenges for Urban Governance: Introduction to the Review Issue. - Urban Studies. 5/6. 845-851. o.

Kickert, W. (ed.) (1997) Public Management and Administrative Reform in Western Europe. Edwar Elgar, Cheltenham.

King, D.S.-Pierre, J. (eds.) (1990) Challenges to Local Government. Sage, London.

Klijn, E.H. (2010) Trust in governance networks: looking for conditions for innovative solutions and outcomes. - Osborne, S (ed.) The new public governance? Routledge, London, New York. 303-322. o.

Kovách I. (2008) Önkormányzati hatalom, projektesítés és az új kormányzás. - Bódi F. (szerk.) A területfejlesztés útjai az Európai Unióban. MTA PTI. Budapest. 13-129. o.

Kovách I. (2009) Hatalom és társadalom 1990 után. Szereplők és forráselosztás. - Bayer J.-Boda Zs. (szerk.) A rendszerváltás húsz éve: Változások és válaszok. MTA PTI - L'Harmattan Kiadó, Budapest. 188-205. o.

Kriesi, H. (1983) Überblick über den gegenwärtigen Stand der Korporatismus-Debatte. - Schweizerische Zeitschrift für Soziologie. 2. 235-256. o.

Kunszt M. (szerk.) (2001) Politikum Pécsett. PTE BTK Politikai Tanulmányok Tanszék, Pécs.

Lauria, M. (ed.) (1997) Reconstructing Urban Regime Theory. Sage, Thousand Oaks, London.

Lewis, N. (1992) Inner City Regeneration. The Demise of Regional and Local Government. Open University Press, Philadelphia.

Lincoln, R. (1977) Organisational Dominance and Community Structure. - Liebert, R.-Imershein, A (eds.) Power, Paradigms and Community research. Sage, London. 121-149. o.

Lord, A. (2009) Mind the Gap. The Theory and Practice of State Rescaling: Institutional Morphology and the 'New' City-regionalism. - Space \& Polity. 2. 77-93. o.

Martin, S. (2010) From nem public management to networked community governance? Strategic local public networks in England. - Osborne, S (ed.) The new public governance? Routledge, London, New York. 337-349. o.

Mezei C. (2006) A települések versenyképességét befolyásoló helyi gazdaságfejlesztési gyakorlat Magyarországon. - Horváth Gy. (szerk.) Régiók és települések versenyképessége, MTA RKK, Pécs. 413-443. o. 
Moss K. (2000) Business Coalitions as a Force for Regionalism. - Katz, B (ed.) (2000) Reflections on Regionalism. Brooking Institution Press, Washington DC. 154-185. o.

Neisser, H.-Hammerschmid (Hrsg.) (1998) Die innovative Verwaltung. Signum Verlag, Wien.

Olsson, J. (2001) Democracy Paradoxes in Multi Level Governance. Paper presented in Gdansk, RSA Conference.

Osborne, S (ed.) (2010) The new public governance? Routledge, London, New York.

Ostrom, E. (2005) Understanding Institutional Diversity. Princeton University Press, Princeton.

Pálné Kovács I. (1990) Helyi politika. Akadémiai Kiadó, Budapest.

Pálné Kovács I. (szerk.) (2005) Regionális reformok Európában. IDEA, Belügyminisztérium, Budapest.

Pálné Kovács I. (szerk.) (2008) Városi kormányzás. - Tér és Társadalom. 1.

Peters, G.-Pierre, J. (eds.) (2006) Handbook of Public Policy. SAGE, London.

Pickvance, C.G. (1997) Decentralization and democracy in Eastern Europe: a sceptical approach. Government and Policy. 2. 129-143. o.

Pike, A.-Pose, R.-Tomaney, J. (2006) Local and regional development. Routledge, Abingdon.

Putnam, R.D.-Leonardi, R.-Nanetti, R. (1993) Making Democracy Work. Civic Traditions in Modern Italy. Princeton University Press, Princeton.

Rast, J. (2005) The politics of alternative economic development: Revisiting the Stone-Imbrosco debate. - Journal of Urban Affairs. 1. 53-69. o.

Rhodes R. (1997) Reinventing Whitehall 1979-1995. - Kickert, W. (ed.) (1997) Public Management and Administrative Reform in Western Europe. Edwar Elgar, Cheltenham. 43-61. o.

Rhodes, R.A.W (ed.) (2000) Transforming British Government. vol.1. Changing Institutions Houndmills, Macmillan.

Roberts, P. (1997) Sustainability and spatial competence: an examination of the evolution, ephemeral nature, and possible future development of regional planning in Britain. - Danson, M.-Lloyd, G.-Hill, S. (eds.) Regional Governance and Economic Development. Pion, London. 7-26. o.

Rückwardt, B. (1978) Koordination des Verwaltungshandelns. Duncker and Humblot, Berlin.

Sabatier, P.A.-Jenkins-Smith, H.C. (1993) Policy Change and Learning: An Advocacy Colation Approach, Westview Press, Boulder, Colo.

Sagan, I. (2009) Regions, New regionalism and regime Theory. - Scott, J.W. (eds.) (2009) De-coding New Regionalism. Franham, Ashgate. 93-113. o.

Schneider, V. (2002) Private Actors in Political Governance: Regulating the Information and Communication Sectors. - Grote, J.R.-Gbikpi, B. (eds.) (2002) Participatory Governance. Political and Societal Implications. Leske+Budrich, Opladen. 245-365. o.

Somlyódyné Pfeil E. (2008a) A közszolgáltatási háló müködésének mintái a Pécsi kistérségben. - Kovács K.Somlyódyné Pfeil E. (szerk.) Függőben. Közszolgáltatás-szervezés a kistelepülések világában. KSZK ROP. Budapest. 255-281. o.

Somlyódyné Pfeil E. (2008b) A városi térségek a közigazgatási struktúra és a „governance” keresztmetszetében. - Tér és Társadalom. 1. 27-45. o.

Stoker, G. (1995) Regime Theory and Urban Politics. - Judge, D.-Stoker, G.-Wolman, H. (eds.) Theories of Urban Politics. Sage, London. 54-72. o.

Stoker, G. (ed.) (2000) The New Politics of British Local Governance, Macmillan Press, New York.

Stoker, G.-Mossberger, K. (1994) Urban regime theory in comparative perspective. - Environment and Planning C. 2. 195-213. o.

Stone, C. (1989) Regime politics. Lawrence. University Press of Kansas.

Stone, C. (1991) The hedgehog, the fox and the new urban politics: rejoinder to Kevin R Fox. - Journal of Urban Affairs. 13. 289-299. o.

Stone, C. (1993) Urban regimes and the capacity to govern: a political economy approach. - Journal of Urban Affairs. 15. 1-28. o.

Stone, C. (1995) Political Leadership in Urban Politics. - Judge, D.-Stoker, G.-Wolman, H. (eds.) (1995) Theories of Urban Politics. Sage, London. 96-117. o.

Stone, C. (2005) Looking back to look forward. Reflections on Urban Regime Analysis. - Urban Affairs Review. 3. 309-341. o.

Sýkora, L.O.-Muliček, O.-Maier, K. (2009) City regions and polycentric territorial development: concepts and practice. - Urban Research\&Practice. 3. 233-239. o.

Swyngedouw, E. (2000) Authoritarian governance, power, and the politics of rescaling. - Environment and Planning D. Society and Space. 18. 63-76. o.

Szirmai V. (2004) A globalizáció és a nagyvárosok társadalmi szerkezete. - Szociológiai Szemle. 4. 3-21. o.

Tavistock Institute (1999) The thematic evaluation of the partnership principle. 
Tocqueville Research Center (2004) A magyar polgármesterek: európai összehasonlításban. http://www.helyidemokracia.hu/eupolgi/polgicelok.html

Tosics I. (2008) Nagyvárosi kormányzás: A város és környéke együttmüködése. Külföldi példák és hazai relevancia. - Tér és Társadalom. 1.3-27. o.

Work, R. (2001) Decentralization, Governance, and Sustainable regional Development. - Stöhr, W.-Edralin, J.Mani, D. (eds.) New Regional Development Paradigms. Greenwood Press, Westport. 21-35. o.

\section{GOVERNANCE OF URBAN SPACES AND THE URBAN REGIMES. ON THE MARGINE OF A STARTING RESEARCH PROJECT}

\section{ILONA PÁLNÉ KOVÁCS}

The article's mission is to provide theoretical basis for a launching project dealing with urban governance in Hungary. The author assumes that the regime theory well known in the Western urban governance literature will be appropriate framework to investigate the main actors, institutions, networks in the governance of urban spaces. There is no doubt that economic and other non public actors matter in governing the cities and their surroundings, but according the hypotheses of the author many differences will be identified stemming from the path, the political-administrative culture, public administrative frameworks of Hungary. However the governance approach and the changing geographical borders of urban administration are unavoidable and hopefully the starting research can contribute to understand the processes going on in urban areas. 
$=$ 